1973

\title{
Brandeis and the Democratic Vision
}

Edward A. Purcell Jr.

New York Law School, edward.purcell@nyls.edu

Follow this and additional works at: https://digitalcommons.nyls.edu/fac_other_pubs

\section{Recommended Citation}

Purcell, Edward A. Jr., "Brandeis and the Democratic Vision" (1973). Other Publications. 398.

https://digitalcommons.nyls.edu/fac_other_pubs/398

This Article is brought to you for free and open access by the Faculty Scholarship at DigitalCommons@NYLS. It has been accepted for inclusion in Other Publications by an authorized administrator of DigitalCommons@NYLS. 
of his declining $y$ 's. Edward Rand noted that Eliot's pronouncements came to amount to not much more than putting "the conventional wisdom into phrases of "lapidary inevitability" "(p. 297). Hawkins shows how the advocate of "organizational solutions to the problems of industrial democracy" kept using the cliche ridden language of the popular social philosopher and urged his listeners to accept the "collectivism which does not suppress individualism" (pp. 298-99). Eliot's achievements, however, are not diminished by such triteness or such inconsistencies. As for the latter, he probably would have brushed them off with a quote from his favorite New Englander, Ralph Waldo Emerson, that consistency was but the hobgoblin of little minds. Eliot brought Harvard and with it the nation's colleges into the modern world; he infused his college with the spirit of free inquiry and gained for higher education a position where it could maintain its precarious independence from the giant centers of powers in the nation's economy and politics. Hawkins' book makes it abundantly clear at what price and with what means Eliot's and Harvard's victories were gained. It shows that in the modern world there cannot be even in academia a sanctuary free of managers and administrators; that the function of higher education's trustees is precisely that rationalizing and merging of interests which will allow the institutions of learning to survive in a world whose clocks do not run on academic time. Hugh Hawkins's book is one of the finest and most judicious studies of the conditions under which modern academic man established his existence in America.

\section{Jurgen Herbst \\ Departments of Educational Policy \\ Studies and of History \\ University of Wisconsin-Madison}

Professor Herbst is the author of The German Historical School in American Scholarship (Ithaca, N.Y.: Cornell University Press, 1965).

\section{BRANDEIS AND THE DEMOCRATIC VISION}

Melvin I. Urofsky and David W. Levy, eds. Letters of Louis D. Brandeis. Vol. I (1870-1907): Urban Reformer. Vol. II (1907-1912): People's Attorney. Albany: State University of New York Press. Vol. I-1971. Pp. xliii +610 , illus., index, $\$ 20.00$. Vol. II-1972. Pp. xxiv +750 , illus., index, $\$ 20.00$. 
Melvin I. Urofsky. A Mind of One Piece: Brandeis and American Reform. New York: Charles Scribner's Sons, 1971. Pp. xiii +210 , bibl. index, $\$ 10.00$.

Ten years ago, when most American historians still wrote from a basically New Deal perspective, they seemed to accept as both inevitable and desirable a society dominated by big business, big government, and big labor. They saw the federal regulatory commission as the administrative instrument through which the government would protect the public interest and keep the machinery of society working smoothly. In 1967 Richard Hofstadter pronounced earlier trust-busting sentiments an "old romance" and pointed to the development of antitrust law into a highly technical and relatively effective method of policing the large-scale corporations that had come by the fifties to be taken for granted. ${ }^{1}$ In such an atmosphere Louis Dembitz Brandeis often seemed an anachronism-brilliant and admirable, to be sure, but still a throwback to the economic beliefs of the nineteenth century.

The publication of the Letters of Louis D. Brandeis is a major contribution to scholarship and is especially timely when there is a new questioning of the economic and political wisdom of the cold war years. The changes of the past half-century have inevitably made many of Brandeis's ideas and proposals seem obsolete, but the values he defended and the problems he confronted have taken on a new relevance. There is a danger in bigness. Democratic values are more fundamental than the demands of corporate, technological convenience. Big government regulation of big business does not guarantee political freedom, economic security, or the common good. What was perhaps Brandeis's essential concern is even more fundamental at the present time than it was in the years before World War I. "In a democracy," he declared in 1913, "it is the part of statesmanship to prevent the development of power which overawes the ordinary forces of man."2 That concern goes to the heart of the question of what type of society we wish America to be and what type of society we have made it.

Melvin I. Urofsky and David W. Levy have been at work on the Letters since 1964, drawing extensively on the Brandeis materials at the University of Louisville, searching out correspondence in other manuscript collections, and obtaining a number of items in private hands. The first two volumes, handsomely published by the State University of New York Press, cover the period from 1870 to 1912 , with the great bulk of the letters written in the years after 1900. The editors have done an excellent job in selection and have provided enlightening and highly detailed notes which supply background information and references to other relevant sources. Compiling such material is often sheer drudgery, but the final result is an admirable and highly useful piece of work. When the final three volumes are completed, the Letters of Louis 
D. Brandeis will stand as a major source in twentieth century American history.

The volumes contain a wealth of information about politics during the Progressive period, revealing nuances of many of its great battles-the New Haven merger fight, the Ballinger-Pinchot affair, and the campaigns of 1912. Perhaps of greatest importance the letters reveal Brandeis the social reformer, not just his ideas and his struggles, but his periodic ups and downs and his shrewd orchestration of reform efforts. Brandeis was a tactician who selected his point of attack, elaborated his tentative solution, and proceeded to organize, inspire, drive, and even goad his forces until they had carried the day or until the fight was finally lost.

And though a battle might be lost, he continually insisted that the future promised new opportunities. Awe-inspiring knowledge of the problems involved, the determined pursuit of influential politicians who seemed reachable, persistent and intelligent use of the public press, and tactful cooperation with diverse allies were his reliable instruments to be used in whatever combination seemed most likely to succeed. Brandeis was in contact, at one time or another, with most of the major reform leaders of the day, with prominent citizens, businessmen, labor leaders, publishers, and writers, and with politicians ranging from minor Massachusetts officials to Theodore Roosevelt, Robert LaFollette, and Woodrow Wilson.

Not satisfied with initial success when a proposal he supported became law, Brandeis persistently turned his attention to the staffing of commissions and the practical problems of implementation. After his success in getting the Massachusetts legislature to establish his plan for savings bank life insurance, for example, he immediately began work on getting the proper men appointed to the board of trustees to ensure the plan's practical success. When the board was completed, all the new appointees were among those whom Brandeis had recommended (Vol. I, p. 591). In spite of inevitable gaps, the letters trace well the evolution of his reform interests, the refinement of his tactics, and the growth of his personal prestige, influence, and confidence.

The letters equally document Brandeis's legendary knowledge of the most complicated and abstruse economic issues, and they suggest the political sources of that approach. Factual mastery was congenial to his mind, and his legal experience had shown him the great utility of fully understanding economic problems. His reform efforts, however, made fact mastery an absolute necessity.

Brandeis was the prototype of a new kind of reformer in American history, one who operated in a new context and employed new tools. Until the late nineteenth century America had lacked powerful centralizing institutions and had remained a relatively unstructured society. While Americans shared many things, perhaps above all a vague democratic ideology, they belonged to a nation of localities. Political, 
economic, and social power was diffuse. During the last thirty years of the century economic productivity and organization expanded at a dizzying rate, and by 1900 the private business corporation had emerged as the dominant structural fact in America. Power had become nationalized; it had become centralized; it had become bureaucratized.

Gradually, from a variety of motives, other forces rallied, attempting to redress the radical imbalance that had developed in the structure of power. Some laws were passed; some reforms achieved. Brandeis was part of the first generation that confronted that new structure. Among his tools were a highly disorganized but occasionally effective public opinion and a handful of rather vague local and national laws. While Brandeis supported various kinds of reform attempts, he devoted much of his time to making available laws serve practical, concrete reform ends. With such tools, and against such an opposition, the complete mastery of economic, financial, and political facts seemed the essential prerequisite for achieving any kind of popular social change.

The new men of organized wealth were insiders. They could make decisions in relative privacy and then carry them out. They had the power to build and buy and do. Brandeis conversely was institutionally an outsider. He had no power himself, and he had to act through public opinion and legislatures, usually reacting rather than initiating. He was an outsider, too, in that the crucial facts on which legal and political decisions ought to be made were often in private hands and difficult or impossible to obtain. He could dispute the Boston Elevated Railroad Company, or Charles S. Mellon of the New Haven, or even President Taft only if he could get enough facts to overcome the advantages of money, power, and control of information that those on the inside possessed.

Brandeis's personal tenacity and his devotion to the mastery of facts enabled him to succeed where others would have failed. His efforts, too, threw into clear relief the extent to which the new economic and political structure in the United States was converting most Americans into institutional outsiders and making it extremely difficult for those who would attempt to defend the interests of the public or of the consumer.

While an outsider to the bureaucratic institutions he battled, Brandeis considered himself the representative of the true public interest, a "public private citizen" (Vol. II, p. 725). He remained throughout his life committed to private property, profit, and even, on occasion, certain kinds of "bigness" in economic organization. He criticized his fellow reformers when they seemed to be "fanatics, \& as ready to do injustice to capital as the capitalists have been ready to do injustice to the people" (Vol. I, p. 437). Brandeis viewed himself as a "conservative" who was attempting to secure the communal well being. That strong personal sense of belonging-of upholding traditional values, of 
fighting for the whole community, and of profoundly belonging to both New England and America-perhaps provided the strength necessary to sustain him in the role of institutional outsider.

The greatest disappointment with the collection, as the editors readily acknowledge, is that it fails to add significantly to our understanding of Brandeis's legal career and thought. This is probably due in large part to the refusal of Brandeis's old law firm to allow the editors to use, or even inspect, the materials in its possession. Brandeis was little interested in jurisprudential speculation and chose not to discuss his cases in his personal correspondence. References to even such an important and public case as Muller v. Oregon appear in only half a dozen letters, and they are invariably brief and unenlightening. There are a handful of interesting comments hidden away, and some discussion of a few legal problems that bore directly on political issues (such as the labor injunction), but they add little to what is already known about Brandeis as lawyer and judge.

In spite of that shortcoming, the letters do suggest the ways in which his reform experience informed his brand of sociological jurisprudence. While Holmes came to his legal theory largely through intellectual influences, Brandeis arrived at his through political ones. His knowledge of social and economic realities not only highlighted the aridity of many legal formulas, but it also convinced him that he could turn such abstractions to his own use. To the extent that liberty of contract was an abstraction, he could, with sufficient factual support, infuse into it his own concrete meaning. Brandeis was perceptive as well as legally shrewd when he cited Locbner v. New York as his major precedent in arguing Muller v. Oregon.

Additionally, the problems he faced in fighting the corporations immediately suggested to him the instrumental nature of law. Unlike defenders of the corporate structure, to whom legal language easily translated into analytically vague but socially serviceable ideology, the outsider who challenged those inside a bureaucracy sought practical leverage through which to change things. Brandeis needed to force legal institutions to alter business practice rather than use them to obscure what already existed. The law necessarily appeared a tool.

Concerned with Brandeis's role in American politics, Professor Urofsky has drawn on his extensive research as coeditor of the Letters to write a series of interpretive essays dealing with some of the major aspects of Brandeis's career. A Mind of One Piece: Brandeis and American Reform is a useful introduction to his life and thought, often suggestive and perceptive. Urofsky succeeds well in laying open the inner coherence of Brandeis's outlook, revealing the values that consistently informed his work and capturing many of the characteristic shadings of his mind. He sheds light, for example, on Brandeis's often ignored commitment to Zionism and convincingly argues that it grew 
from his belief that the ideals of Zionism paralleled the ideals of American progressivism, rather than from any initial sense of Jewish identity or religion.

Urofsky suggests that a handful of individuals, such as Brandeis and Jane Addams, were crucial to progressive success. Because of their personal prestige, unflagging energy, and diverse political connections, the author maintains, such individuals served as "linchpins" which "helped hold together that amorphous mixture of reformers and ideas and uplift we have termed progressivism" (p. 167). Such an interpretation flows readily from the Letters and clearly pinpoints one of the characteristics of progressive politics. Urofsky, however, threatens to push it too far when he declares that "reform, after all, is not primarily a social or institutional phenomenon, but the collective result of many individual efforts" (p. 167). That the individual reformer was crucial is certain, but, as with any other historical "cause," the reformer must be seen in a complete social and institutional context. Urofsky would surely not deny that; and his reemphasis on the individual, taken with a certain caution, is welcome.

While his essays are generally sympathetic, Urofsky maintains that the antitrust program Brandeis and Wilson advocated in 1912 was doomed to fail because it "attempted the impossible: to turn back historical progress" (p. 80). Comparing that antitrust policy to Jackson's assault on the Bank of the United States, the author concludes that "it was an exercise in futility; the conditions that made the trusts possible also guaranteed their continuance" ( $p$. 79). While pointing to the love Americans have for bigness and "the facts of economic reality," however, Urofsky does not specify exactly which conditions "guaranteed" that continuance, to what extent those conditions were technological and to what extent political, and whether some or all of them could possibly have been changed.

And though he indicates that Wilson did not fully understand Brandeis's goals, Urofsky does not discuss the significance of Wilson's weak, probusiness appointees to the Federal Trade Commission. Those appointees scuttled the new FTC and destroyed whatever chance it had to enforce the antitrust laws along Brandeisian lines. It was thus politics, not technological inevitability, that frustrated the commission's reform potential. Brandeis, who always thought in terms of practical implementation, was bitterly disappointed. "It was a stupid administration," he later commented. ${ }^{3}$

Finally, even if one accepts, as Urofsky apparently does, the economic inevitability of giant corporations, that does not mean that the existing corporate structure itself is historically or economically unavoidable. It might be possible, for example, to have industrial giantism but with a different social and financial structure of ownership and control. 
Urofsky rightly points out that Brandeis, in spite of his factual orientation, was more a moralist than an economic technician. This, however, does not mean that his hostility to corporate size and dominance was misguided, unless one assumes that there was only one "efficient" solution to the problem of economic organization and that politicomoral values must be subordinated to that solution. Probably neither Professor Urofsky nor most scholars would accept those two assumptions, and yet until recently the work of most historians has dismissed Brandeis's economic goals as impractical. Very possibly they are impractical in an immediate political sense, but that does not mean that they are impractical forever or necessarily. The fact that they might well be practicable, but have never been given a real chance at implementation, surely tells us more about America than does any assumption of the ineluctible progress of economic and financial centralization.

Perhaps part of the reason for ignoring Brandeis's economic ideas has been the focus on such terms as "trusts" and "monopolies." Those words served a largely rhetorical purpose and, since World War II, seem quaint. To Brandeis, however, they described real entities and real economic practices. When he criticized the New Haven, or the United Shoe Company, or J. P. Morgan's control of credit, he had specific examples of behavior in mind that were restrictive, unfair, and socially harmful-in his words, "monopolistic." Brandeis attacked bigness as a "curse," but he was no dogmatist. Rather he continually asked one fundamental question: what impact does any particular organization or practice have on the lives, freedoms, and dignity of individuals? When the consolidation of economic efforts seemed to promise real advantages in working toward some popular, democratic goal, he could approve them. But always he asked for their full human meaning.

To fully evaluate Brandeis's significance, therefore, it is necessary to get behind his language and face the crucial political problem that he persistently confronted: the dangerous threat that private, concentrated wealth and power pose to democratic freedoms. The real question is not of "monopoly," either as rhetoric or pure theoretical reality, but of inordinate power exerted by a few over the lives of all and the politics of the nation. Brandeis's commitment to small-unit economics may need major qualification; his concern for entrepreneurial opportunities for the individual may well speak to another age. His conviction that the individual should control his own life and participate in an open and meaningful democratic process, however, speaks fully to the present.

Regardless of the minor successes and major failures of national antitrust policy, the central danger that worried Brandeis still plagues America. In articulating the idea that political freedom and the widespread dispersal of economic power are intimately related, he reminds us of one of the cardinal principles in republican political 
theory that traces back to the Federalist Papers, Locke, Harrington, and beyond, a principle that many Americans have found it convenient to proclaim outmoded. Fortunately, Brandeis's voice still rings clear: political freedom and individual dignity are primary values, and economic organization in a true democracy must be adapted to them.

Edward A. Purcell, Jr.

Department of History

University of Missouri-Columbia

Professor Purcell is the author of The Crisis of Democratic Theory: Scientific Naturalism and the Problem of Value (Lexington: The University Press of Kentucky, 1973), winner of the Organization of American Historians' Frederick Jackson Turner Prize in 1972.

1. Richard Hofstadter, "What Happened to the Antitrust Movement?" in The Paranoid Style in American Politics and Other Essays (New York: Vintage Books, 1967), p. 188.

2. Quoted in Alpheus Thomas Mason, Brandeis: A Free Man's Life (New York: The Viking Press, 1946), p. 419.

3. Quoted in Arthur S. Link, Woodrow Wilson and the Progressive Era (New York: Harper \& Row, 1963, paperback ed.), p. 74. 